\title{
On the Mesencephalic Trigeminal root cells in the Brain of Megalobatrachus japonicus (Temminck)
}

\author{
By \\ Takeshi Kato and Tadashi Kagami \\ Department of Anatomy, Hiroshima Medical College, Kure, Japan \\ (Director: Prof. N. Suzuki) \\ With 3 Text-figures

\section{Introduction}

As already well known, the mammalian brain presents a reduction in the size and importance of the tectum of the midbrain, because this region no longer officiates in its former important capacity in relation to visual and auditory functions. And moreover, the collicular portion of the midbrain in mammals has ceased to serve as the end station for the somesthetic pathway, which has shifted its relay station forward into the optic thalamus and its end station into the cerebral cortex. But in lower forms, the tectum opticum receives and correlates the visual and somesthetic impulses. In selachians, it is exclusively visual in function and is also the same in the bony fish and ganoids. In amphibians, the tectal region shows a still further subdivision consequent upon the appearance of the newly differentiated system of receptors for the cochlear system and the development of structure forming the middle ear.

The large globular cells of origin of the mesencephalic trigeminal root or the nucleus magnocellaris tecti (Comp. Johnston, '05, p. 365) are peculiarly demonstrated in the tectum opticum, and yet whether these cells in the early developmental stage are derived from the neural crest or even the alar plate as suggested by Windle and Fitzgerald ('42, p. 607)' or by Ranson ('49, p. 78) is uncertain (Comp. Piatt '45, p. 36). On the while, many investigators, such as Kosaka ('12),

1) Windle and Fitzgerald have indicated a possibility that some of them come migratory trigeminal motor neuroblasts has been suggested in the human and cat embryos. 
Allen ('19), Weinberg ('23), Schneider ('28), Sheinin ('30), Raven ('35) and others, have mentioned similarity of these cells to those of the cerebrospinal ganglia or Rohun-Beard cells of spinal cord which are derived from the neural crest.

The morphological, functional or developmental correlation of the mesencephalic trigeminal nerve and its root cells in lower vertebrates have been repeatedly studied by many authors, such as Johnston in Scyllium carnicula and Necturus ('05), van Valkenburg in Alligator sclerops ('20), Ariëns Kappers in Alligator sclerops ('20), Sheinin in the dog ('30), C. J. Herrick in Necturus ('14, '17) and Amblystoma ('36, '48), Huber and Crosby in Reptilia ('33), Piatt in Amblystoma ('45, '46), Pearson in Opossum ('49) and many others,

The well myelinated fibers arising from these cells pass back toward trigeminal roots close to the periventricular gray. The influence of this system of receptors upon the differentiation of the tectum opticum, however, is kept in dark as denoted by Herrick in Amblystoma ('36, p. 346).

In the brain of Megalobatrachus japonicus, the subdivision of the collicular region is obscure and the interbigeminal sulcus as shown by Tilney and Riley in Amphibia ('28, p. 492) can scarcely be noticed, but the special appearance of mesencephalic trigeminal root cells are evidently remarkable in its size and location.

\section{Material and Methods}

This communication, therefore, is based upon the study of the brains of adult Megalobatrachus japonicus prepared by various methods, such as Weigert's method (transverse and sagittal in serian sections), hematoxylin-eosin double deying (transverse), so-called Sugamo's method (transverse and sagittal) and Pal-carmine deying (sagittal).

\section{Description and Discussion}

In our series, the mesencephalic trigeminal root cells may be briefly divided into two groups of medial and caudal, contrary to the classification of Johnston ('05) or van Valkenburg ('11) who divided into three groups of medial, lateral and intermedial. The large cells of these groups (ca, 20-40 $\mu$ in diameter) are conveniently divided into three types of large, medium-sized and small as demonstrated by 
Schneider ('28, p. 326). Some of these cells are apparently multipolar or bipolar and the others unipolar as shown by Schneider in dog ('30, p. 326) or by Huber and Crosby in Reptilia ('26, p. 139), opposed to the description of Ranson in mammals ('49, p. 189). While, on the contrary, Sargent ('04) described the nucleus magnocellaris tecti in Raja, Squalus and Mustelus, and indicated that each cells has three processes, one of a dendritic character which receives impulses from the optic tract fibers, and an axon which enters into the formation of Reissener's fiber, and a third process which he calls the cerebellar neurite.

The medial group of cells are widely scattered in all layers of the stratum griseum throuhgout the tectum opticum. The lateral portion of the gray is scant of cells, while in the mid-dorsal plane of the brain, these cells are gradually increased in number. At first, they are mostly situated in the superfical layer of the gray and spread forward into its rostral margin. Further mesial tracing, these cells are distributed in all layers of the gray even down to the ependymal border and its localisation is somewhat dissimilar with the demonstration of Huber and Crosby in Alligator sclerops ('26, p. 198)'1).

The other caudal group of cells appears in the caudal portion of the tectum at the primordial inferior colliculus at just dorsal region of the nucleus posterior tecti ${ }^{2}$ and makes the dense group or nest of cells intermingled with small granular cells as already mentioned by Herrick in Necturus ('17. p. 283) or Amblystoma ('48, p. 178). Besides, Herrick denoted that the cells of the mesencephalic 5th nucleus are found sparecely scattered in the cerebellar gray (' 48, p. 140) and suggested that these cells are first differentiated at the posterior end of the tectum and that from this focus its cells spread formard into the optic section in smaller number, backward into the cerebellum ('48, p. 174). Pearson denoted in the brain of young opossum that the cells of origin of the mesencephalic trigeminal root are scattered along this fiber path from the junction of the diencephalon and mesencephalon caudully through the midbrain and into the pons and the cerebellum ('49, p. 169). Furthermore, Voris and Hoeer ('32) and Larsell ('35) have

1) According to the figures of Huber and Crosby in Alligator sclerops ('26. p. 198), these cells are situated just under the commissure of the superior colliculus, in midline and between it and the ventricle.

2) The nucleus posterior tecti has just been mentioned as a special area at the caudal end of the tectum which contains particularly dense group of neurons with thick dendrites (Comp. Herrick's paper, '17, p. 283). 
pointed out that the large globular cells in the base of the cerebellum of the opossum are identical with the cells of mesencephalic trigeminal root. But we were unable to find any in the cerebellar gray as described by Piatt ('45, p. 39), although somewhat large cells (ca. 19-24 $\mu$ in diameter) are dlffusively distributed at the basal area of the cerebellar alba. We, therefore, suggest that some of the large multipolar cells from the caudal group have spread forward into the laminated gray matter as shown in the description of Ranson in mamals ('49, pp. 197-198).

As indicated above, the mesencephalic trigeminal root and cells are evidently well developed comparing with the relatively reduced appearance of other systems of fibers and cells in the brain of Megalobatrachus japonicus. It is now generally recognized that the mesencephalic trigeminal root and cells constitute a proprioceptive apparatus chiefly from the musculature of the jaws as noticed in the descriptions of Schneider ('23, p. 334), Piatt ('45, p. 35) and others. Its evident importance is accentrated by the experimental demonstration that these fibers in the cat are distributed periphery to both muscles of mastication and the deep tissues associated with the teeth and palate (Comp. Corin, '40). In Megalobatrachus japonicus, consequently, it seems probable that some intimate correlation between the peculiar occurrence of the cells of the mesencephalic trigeminal root and the strong development of the above-mentioned organs may positively be suggested.

\section{Concluding Remarks}

1. In this communication, the morphological research on the mesencephalic trigeminal root cells in the brain of Megalobatrachus japonicus has been mentiond.

2. The cells in question are divided into three types of large, medium-sized and small. They mostly multipolar or bipolar and the others unipolar.

3. The globular cells are generally classified into two groups of medial and caudal. The cells of the former group are widely scattered in all layers of the stratum griseum throughout the tectum. The lateral portion of the tectal gray is scant of cells, while those of the medial plane of the brain are gradually increased in its number. Further medial tracing, these cells are distributed in all layers of the gray even down to the ependymal border. The caudal group of cells lies in the caudal portion of the tectum at just dorsal region of the nucleus post- 
On the Mesencephalic Trigeminal Root Cells in the Brain of Megalobatrachus.

terior tecti showing the group or nest of large cells.

4. These cells were unable to find any in the gray of the cerebellar body, although somewhat large cells are freely confounded at the basal area of the cerebellar alba and the reduced anterior medullary vellum, so that we suggest that some of the large cells from the caudal group have spreaded forward into the laminated gray matter,

5. In this animal, it, therefore, seems probable that some positive correlation between the peculiar occurrence of the cells of the mesencephalic Vth nerve and the proprioceptive apparatus chiefly from the musculature of the jaws may be suggested.

\section{Bibliography}

1. Allen, W. F. 1919. Application of the Marchi method to the study of the radix mesencephalica trigemini in the guinea pig. J. Comp. Neur., vol. 30, pp. 169-216.

2. Ariëns Kappers, C. U., Huber, G.C. and Crosby, E.C. 1936. The comparative anatomy of the nervous systems, including man. Macmillan Company, New York.

3. Corbin, K. B. 1940. Observations on the peripheral distribution of fibers arising in the mesencephalic nucleus of the fifth cranial nerve. J. Comp Neur., vol. 73, pp, 154-177.

4. Clark, Sam L. 1926 Nissl granules of primary afferent neurons. J. Comp. Neur., vol. 41, p. 143.

5. Edinger, L. 1901. Das Cerebellum von Scylium carnicula. Arch. f. mikr. Anat. Bd. 58, pp. 661-678.

6. Herrick, C. J. 1917. The internal structure of the midbrain and thalamus of Necturus. J. Comp. Neur., vol. 28, no 2, pp. 235-348.

7. 1947. The brain of tiger salamander. The University of Chicago Press. Chicago, Illinois:

8. Huber, G. C. and Crosby, E. C. 1926. On the thalamic and the tectal nuclei and fiber paths in the brain of the American alligator. J. Comp, Neur., vol. 40, no. 1.

9. - 1933. The reptilian optic tectum. J. Comp. Neur., vol. 57, no. 1.

10. - 1933. A phylogenetic consideration of the optic tectum. Proc. Nat. Aca. Sci., vol. 19 , pp. 15-22.

11. - 1934. The influence of afferent paths on the cytoarchitectonic structure of the submammalian optic tectum. Psych. en Neurol. Bladen, pp. 457-474.

12. Johnston, J.B. 1905. The radix mesencephalica trigemini. The ganglion isthmi. Anat. Anz., Bd. 27.

13. Larse11, C. 1920. The cerebellum of Amblystoma. J. Comp. Neur., vol. 36, pp. 87112.

14. Pearson, A.A. 1949. Further observations on the mesencephalic root of the trigeminal nerve. J. Comp. Neur, vol. 91, no. 2, pp. 147-194.

15. Piatt, J. 1945. Origin of the mesencephalic V root cells in Amblystoma. J. Comp. Neur, vol. 82, pp. 35-53.

16. - 1946. The influence of the peripheral field on the development of the mesencephalic V nucleus in Amblystoma. J. Exper. Zool., vol. 102, pp. 109-141. 
17. Ranson, S.W. 1949. The anatomy of the nervous systems., its development and function. Philadelphia and London, W. Saunders Company.

18. Schneider, A. J. 1928. The histology of the radix mesencephalica N. trigemini in the dog. Anat. Rec., vol. 38, pp. 321-339.

19. Sheinin, J. J. 1930. Typing of the cells of the mesencephalic nucleus of the trigeminal nerve in the dog, based on Nissl granule arrangement. J. Comp. Neur., vol. 50, pp. 109-131.

20. Tilney, F. and Riley, H.A. 1928. The form and functions of the central nervous system. Paul B, Hoeber, Inc. New York.

21. van Valkenburg, C. T. 1911. Zur vergleichenden Anatomie des mesencephalen Trigeminusanteils. Folia neurobiol., Bd. 5.

22. Voris, H.C. and Hoerr, N.L. 1932. The hindbrain of the opossum, Didelphis virgineiana. J. Comp. Neur., vol. 54, pp. 277.355.

23. Weinberg, E. 1928. The mesencephalic root of the fifth nerve. A comparative study. J. Comp. Neur., vol. 46, pp. 244-405.

24. Windle, W.F. and J. E. Fitzgerald, 1947. Development of the human mesencephalic trigeminal root and related neurons. J. Comp. Neur., vol. 77, pp. 597-608.

\section{Supplementary Note}

Lastly it is a great pleasure to me to tender my thanks to Dr. C. Judson Herrick (Professor Emeritus of Neurology, The University of Chicago) for his constant advice and his kindness of sending me his numerous original reprints and the precious monograph titled "The Brain of the TigerSalamander". Grateful Acknowledgement is also made to Late Professor C. U. Ariëns Kappers (the late director of the Dutch Central Institute of Brain Research at Amsterdam), Professor B. Brouwer (the present director of the same institute) and Dr. J.L. Addens (the same institute).

Kure, Japan

N. Suzuki

3, March, 1951

\section{Abbreviations}

Åii figures are of adult Megalobatrachus japonicus (Temminck)

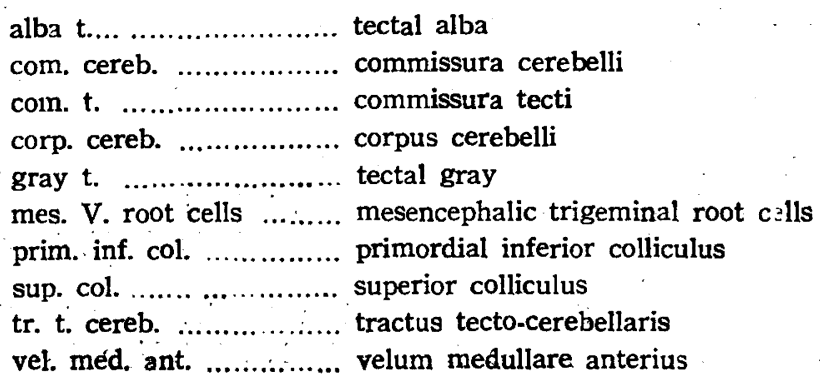




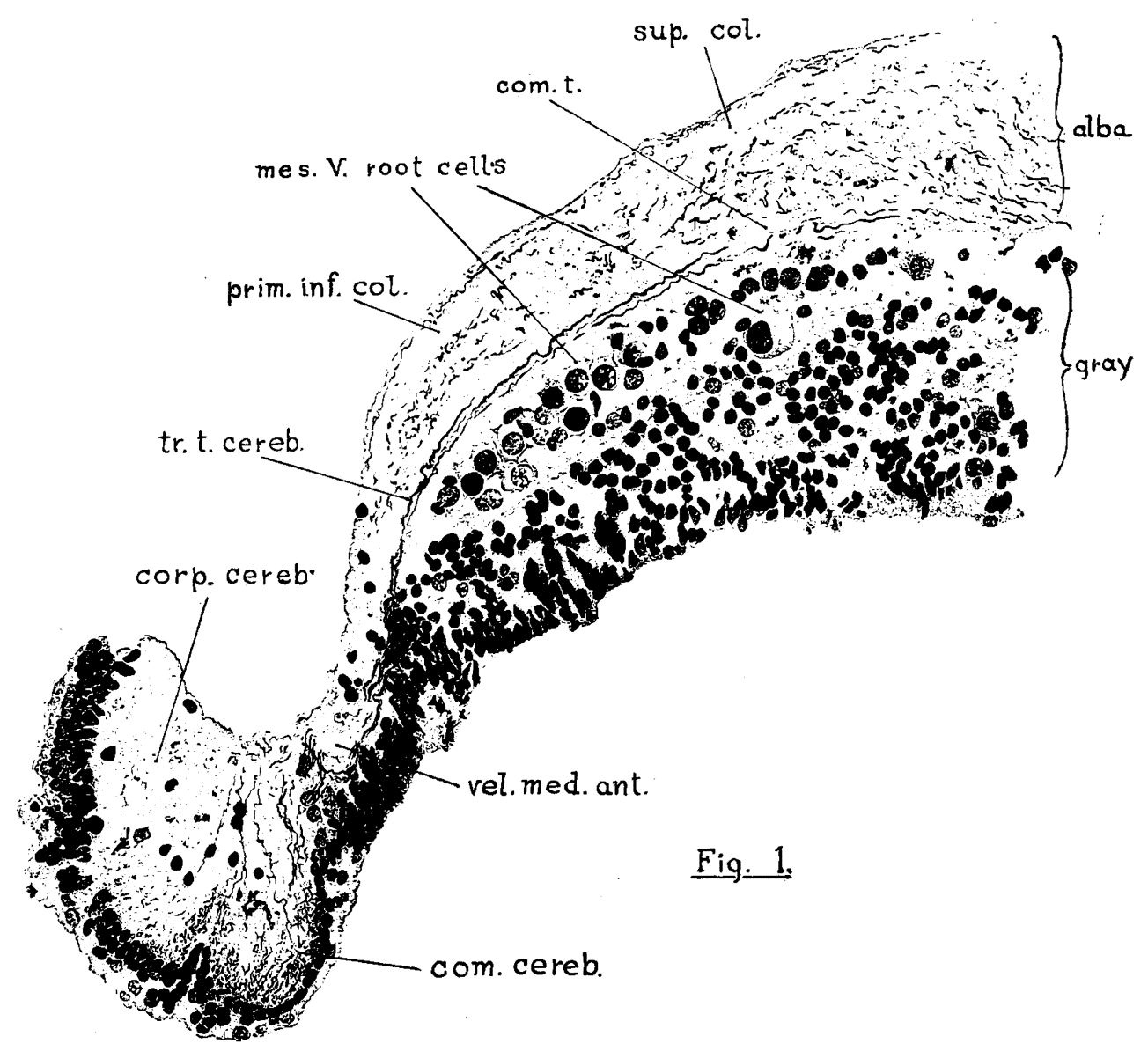




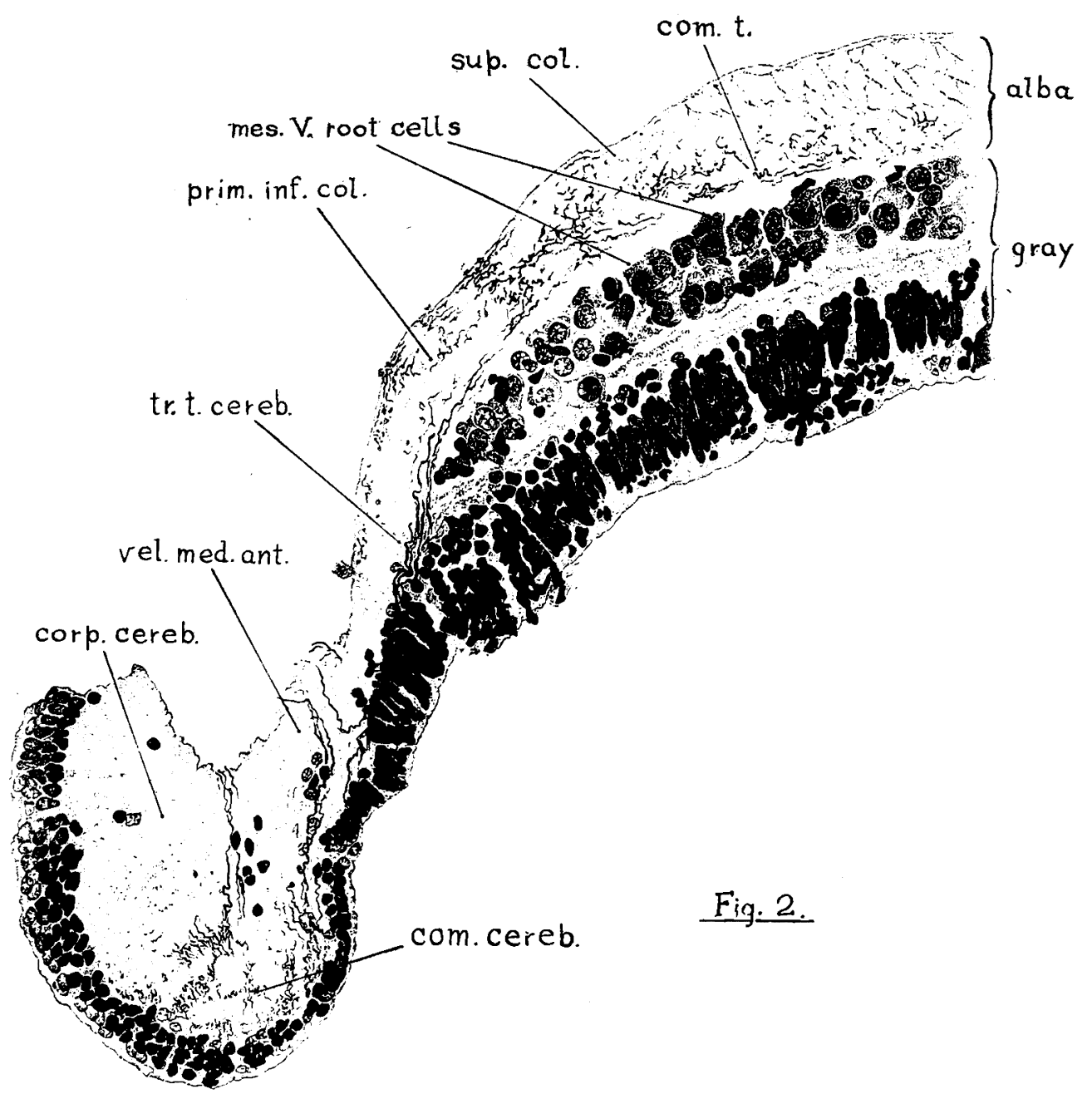


ON THE MESENCEPHALIC TRIGEMINAL ROOT CELLS IN THE BRAIN PLATE III

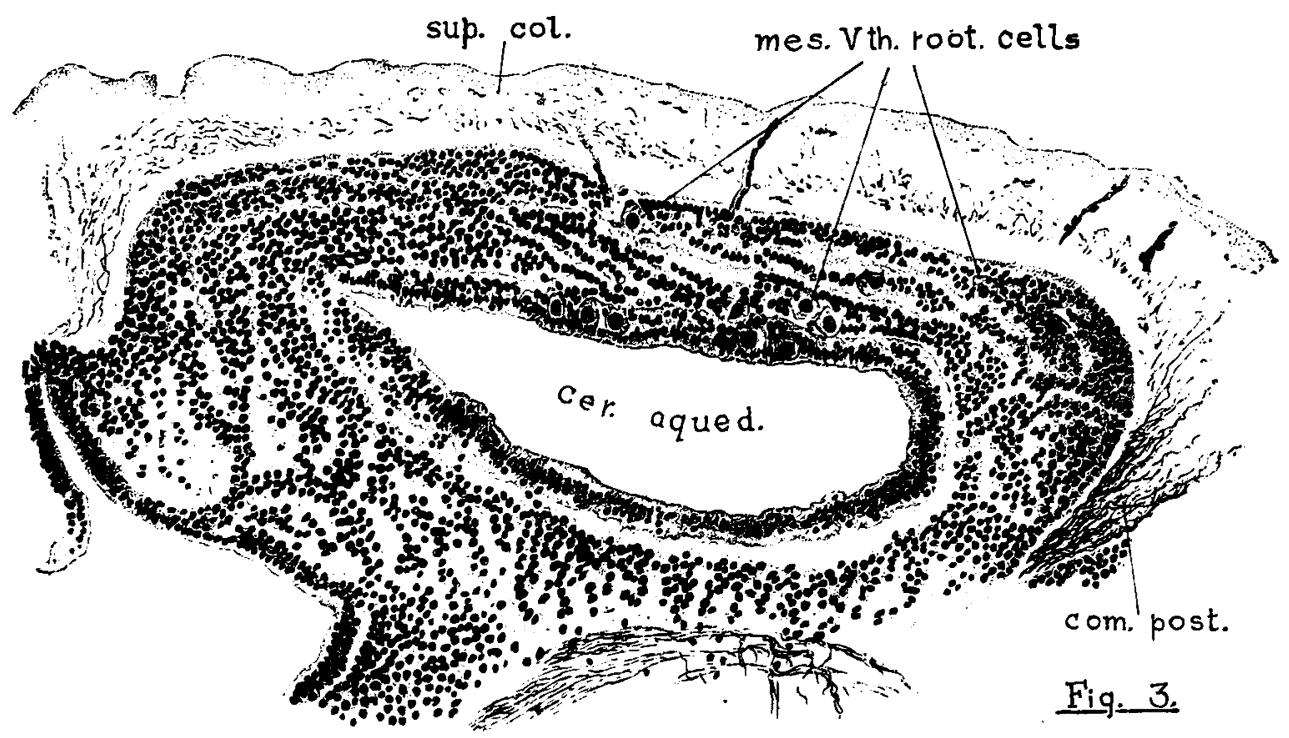


On the Mesencephalic Trigeminal Root Cells in the Brain of Megalobatrachus. 271

Fig. 1. The sagittal section passes through the median plane of the brain of this animal and showing the caudal portion of the tectum opticum and the cerebellar body.

Pig. 2. The sagittal section passes through the median plane of the brain of this animal and takes about $0.1 \mathrm{~mm}$. more medially. It includes the caudal group of cells of origin of mesencephalic trigeminal root.

Fig. 3. The sagittal section passes through the more medial plane of the brain of this animal and showing the middle portion of the laminated tectum opticum. It includes the mesencephalic trigeminal root cells which distribute the all tectal layers even down into the ependymal layer. 